\title{
DESAIN PEMBELAJARAN LITERASI KITAB KUNING MELALUI METODE SOROGAN DALAM MENINGKATKAN PEMAHAMAN AGAMA ISLAM
}

\section{Zaky Fajar Taufiqurrahman, Habibi Al Amin}

Program Pascasarjana Universitas Hasyim Asy'ari Tebuireng Jombang, Jombang, Indonesia, Universitas Hasyim Asy'ari Tebuireng Jombang, Jombang, Indonesia Email: mynameiszaky@gmail.com, habibi.alamin@gmail.com

\begin{abstract}
Abstrak
Desain pembelajaran, merupakan cetak biru yang berisi akan materi, tujuan dan evaluasi. Sedangkan literasi kitab kuning adalah kemampuan untuk membaca, menulis dan mengulangi kembali kalimat yang telah diajarkan. Tujuan dalam riset ini, yaitu 1) Untuk mendeskripsikan Desain Pembelajaran Literasi Kitab Kuning Melalui Metode Sorogan Di Pondok Pesantren Tebuireng Jombang, 2) Untuk mendeskripsikan, mengetahui dan menganalisis implementasi Desain Pembelajaran Literasi Kitab Kuning Melalui Metode Sorogan dalam meningkatkan Pemahaman Agama Islam di Pondok Pesantren Tebuireng Jombang, dan 3) Untuk mendeskripsikan, mengetahui dan menganalisis faktorfaktor penghambat dan pendukung serta solusi dalam Implementasi Desain Pembelajaran Literasi Kitab Kuning dengan Metode Sorogan. Penelitian ini menggunakan metode kualitatif, dengan pendekatan studi kasus. Hasil penelitian tersendiri dimulai dengan pembacaan Ummul Kitab oleh guru, dilanjutkan dengan mengabsensi para santri, kemudian para santri mulai menyetorkan bacaan berupa kitab tanpa makna kepada guru, kemudian guru akan memberikan pertanyaan mengenai materi yang dibaca dan materi tambahan, kegiatan ditutup dengan membaca hamdalah
\end{abstract}

Kata Kunci: Desain Pembelajaran, Literasi Kitab Kuning, Pemahaman Agama Islam

Learning design is a blueprint that contains materials, objectives and evaluations so as to facilitate in every learning activity. Yellow literature means they can to reading write and repeat sentences that have been taught. The purpose of this research is: to describe Design Literacy Learning of The Yellow Book Through the Sorogan Method of Tebuireng Islamic Boarding School Jombang, implement the sorogan method in improving the understanding of Islamic religion in Tebuireng Islamic Boarding School Jombang, and What Are the Inhibiting Factors, Supporters and Solutions in the implementation of Yellow Book Literacy with sorogan methods to Improve Understanding of Islam in Tebuireng Islamic Boarding School Jombang. This research uses qualitative approach, with a case study approach. The results of research, itself began with the reading of the Ummul Kitab by the teacher, followed by licensing the students, the activity closes by reading hamdalah.

How to cite:


Keywords: Learning Design, Yellow Book Literacy, Understanding of Islam

\section{Pendahuluan}

Dari sekian permasalahan pada umunya, menjadi titik terlemah dalam lingkup edukasi ialah kurangnya pengkajian (Sanjaya, 2019). Pelajar tidak mendapatkan dorongan dalam anak kurang didorong untuk meluaskan akan potensi intelektual. Pembelajaran yang bersifat tertutup berfokus pada kesanggupan siswa dalam menyimpan segala hal. Otak anak dipaksa untuk mengingat dan menghafal berbagai informasi tanpa harus memahami kabar berita yang mereka ingat dari kehidupan seharihari. Karena itu, siswa kami secara teoritis cerdas ketika mereka lulus, tetapi diterapkan dengan buruk

Secara konseptual, desain pembelajaran adalah praktik menghasilkan alat dan konten atau materi pembelajaran agar proses pembelajaran menjadi seefektif mungkin (Abdul, 2012). Proses yang disebutkan dalam ikhtisar mencakup mengidentifikasi kebutuhan belajar siswa, mengidentifikasi tujuan pembelajaran, dan membuat kegiatan atau "intervensi" untuk mencapai tujuan pembelajaran. Idealnya, proses tersebut didasarkan pada teori pembelajaran yang efektif. Hasil belajar dapat berupa perubahan perilaku siswa, yang dapat diamati dan diukur secara langsung maupun tidak langsung

Implementasi dalam dalam arti umum, adalah orang yang melakukan tindakan atau rencana yang dilakukan dengan cermat dan detail (terampil).Sedangkan lembaga pendidikan yang bersifat pribadi adalah suatu jalur didikan yang diselenggrakan sebagai satu kesatuan sistemik edukasi dan mempunyai nilai kekhususan. Misalnya yaitu pondok pesantren, kelompok bimbingan kursus, lembaga traning, serta satuan pendidikan yang sejenis,

Adapun kata literasi disini, bermakna kesanggupan membaca dan menulis. Kemampuan tersebut sangatlah penting mengingat bahwasanya didalam lingkungan Pondok Pesantren yang mayoritas kegiatannya diisi dengan mengaji menggunakan Kitab Kuning.

Dunia tradisi Islam menghidupi dan melestarikan budaya agamis yang diturunkan oleh para pendahulu selama rentan waktu yang cukup lama. Yayasan keagamaan ini secara faktual telah membuktikan dedikasinya sebagai lembaga yang memberikan pendidikan dan pencerahan bagi masyarakat. Pondok pesantren sendiri memiliki arti tempat para santri belajar agama. Ma'had Daini Islami merupakan salah satu lembaga studi nonformal yang sudah terlihat hasil dalam sejarah perkembangan negara (Azra \& Islam, 2002).

Peninggalan Islam klasik yang berbentuk manunskrip biasanya dikenal dengan istialah "yellow book" yang dipengaruhi oleh cetakan warna pada media (Van Bruinessen, 1995). Pada istilah yang lain menyebutkan bahwa kitab kuning adalah lembaran-lembaran kertas yang berisikan tulisan-tulisan Arab tanpa tanda (harakat) yang sangat familiar bagi kalangan santri.

Madjid, 1997 Kitab Kuning telah lama menjadi bahan ajar bagi santri, sehingga memiliki kedudukan dan peran yang sangat penting di kalangan para penuntut ilmu. 
Istilah tersebut sangat akrab pada ruang lingkup tersebut. Pesantren dan Buku Kuning adalah dua aspek yang tidak bisa dipisahkan dari dunia pendidikan Islam di Indonesia. Ada sistem pentranferan ilmu dimana bersifat khususiyah individu terhadap atau golongan hamba pada kiyainya untuk diajari kitab tertentu, atau biasa disebur dengan sorogan. Penggunanan sistem ini berlaku pada santri yang cukup paham akan nahwu dan shorof, tertentu khususnya memiliki keinginan kelak esok memerankan sosok guru.

Tata cara sorogan merupakan seseorang murid menghadiri pengajar ketika hendak melisankan sebagian baris Al- Quran ataupun bahan ajar yang menggunakan literasi asing serta mengartikan huruf serta kalimat kedalam bahasa tertentu yang pada giliranya pelajar mengucapkan ulang serta mengartikanan kata perkata sesama bisa jadi dengan yang dicoba gurunya (Dhofier, 1982).

\section{Metode Penelitian}

Jenis penelitian ini adalah Penelitian kualitatif. Secara bahasa ini adalah penelitian yang berusaha memahami fenomena yang dialami oleh subjek penelitian, seperti tingkah laku, opini, kemauan, dan kegiatan (Burhan, 2007). Dijelaskan dalam istilah kata dan bahasa secara umum dan dalam konteks alami tertentu, dengan menggunakan segala kaidah rasional.

Di dalam peneliti menggunakan jenis studi kasus sebagai pendekatan. Studi kasus itu sendiri adalah studi "sistem kendala" atau "satu kasus / banyak kasus", yang dapat dilakukan melalui pengumpulan data yang terperinci dan penggunaan sumber informasi gaya "kaya" dalam konteks.

Sebuah studi yang menjaga integritas subjek studi, dengan fokus pada masalah kedalaman dan detail. Data dan informasi yang dikumpulkan peneliti dibentuk menjadi satu kesatuan yang terintegrasi untuk mengembangkan gagasan tentang tema penelitian. Data merupakan fakta yang di kumpulkan peneliti, baik yang berupa angka maupun fenomena. Pada istilah lain data adalah segala fakta dan angka yang di jadikan bahan untuk menyusun suatu informasi, sedangkan informasi adalah suatu data yang telah di proses dan diubah menjaid konteks yang berartu sehingga memiliki makna dan nilai bagi penerimannya dan biasa digunakan untuk pengambilan keputusan.

1. Sumber data di dalam sebuah penelitian adalah sebuah faktor yang sangat penting, karena sumberdata tersebut akan menentukan kualitas dari hasil penelitian itu sendiri. Maka dari itu, sember data akan menjadi sebuah keputusan dalam menentukan sebuah metode dalam pengumpulan data.

Sumber data terbagi:

a) Kepala /Wakil Kepala Pondok,

b) Kepala MudirTakhasus,

c) Guru Takhasus

d) Santri

Data sekunder adalah kumpulan berkas yang dipakai sebagai penguat dan pendukung dalam sebuah observasi. Sumber data primer dan sumber data sekunder. Sumber data primer adalah seorang informan sebagai berikut: 


\section{Teknik Pengumpulan Data}

Pengumpulan data adalah langkah yang dilakukan dalam rangka menghimpun semua hal yang memiliki sangkut paut dalam mencapai tujuan akhir penelitian.

Berikut beberapa teknik pengumpulan data:

1. Observasi, pengkaji pergi ke lokasi untuk membuktikan sendiri mengenai fukus masalah yang diteliti.

2. Wawancara, langkah yang dilakukan dalam mencari sumber data yang komunikasi dialog dari objek yang diteliti.

3. Dokumentasi, merupakan cara yang lazim dilakukan pada setiap riset. Teknik ini selalu menjadi bukti penguat bahwa telah dilaksanakan sebuah pengkajian terhadap suatu permasalahan.

4. Analisis data merupakan hal yang sangat penting dalam tahap ini, dikarenakan pada bagian ini sangat berfungsi mengenai semua eksplorasi yang dilakukan.

Analisis bisa dijalankan Ketika pada tahap pengumpulan ataupun penyortiran telah selesai. penggabungan berkas, data dikumpulkan menentukan akan dibawa ke arah mana penemuan ilmiah, jika dianalisis dengan teknik yang benar.

\section{Pembahasan}

\section{Desain Pembelajaran Literasi Kitab Kuning Melalui Metode Sorogan.}

a. Ciri khas Desain

Identiknya desain yang diterapkan di Pondok Pesantren meliputi kurikulum yang digunakan, lingkungan pembelajaran, faktor internal dan eksternal dalam belajar, serta merancang prosedur kerja yang bertujuan untuk membantu proses pembelajaran santri dan mencapai tujuan yang telah ditetapkan lembaga terkait.

b. Kelebihan Desain Pembelajran metode Sorogan

1. Memiliki pengalaman tersendiri bagi santri yang dapat langsung belajar dengan Kiai

2. Komunikasi yang efektif antara santri dan guru

3. Pembelajaran lebih dalam dan jelas, sehingga dapat mengurangi terjadinya kesalahpahaman dalam segi makna atau penjelasan.

4. Secara langsung mereka dituntut agar lebih disiplin tinggi terhadap ilmu.

5. Bisa dikontrol, dievaluasi dan diketahui perkembangan serta kemampuan diri santri.

c. Kekurangan

1. Menuntut kesabaran tinggi, kerajinan, dan ketaatan diri sendiri

2. Memerlukan waktu yang tidak sebentar dalam prosesnya

3. Jumlah yang bisa mengikuti kelas ini sangat dibatasi

\section{Implementasi Metode Sorogan Dalam Meningkatakan Pemahaman Agama Islam Pondok Pesantren Tebuireng Jombang?}

\section{a. Penerapan Pembelajaran}


Pondok Pesantren Tebuireng adalah lembaga pendidikan Islam yang mengabungkan pendidikan umum dan salaf dalam penerapanya. Pada pendidikan formal sudah tersedia dari jenjang menengah sampai atas sedangkan untuk nonformal tersedia unit muallimin. Untuk pendidikan didalam pondok majelis ilmi menjadi penanggung jawab mengenai pembelajaran salaf kepada para santri.

Dalam pelaksanaan sendiri diadakan kelas pengajian takhasus yang dilaksanakan seusai sholat magrib dan bertempat di serambi masjid dan sekitarnya. Terdapat berbagai tingkatan kelas dengan sistem pembelajaran yang berbeda dan sesuai dengan kemapuan para santri. Sorogan tersendiri memiliki beberapa syarat yang harus dimilki agar dapat mengikuti. Para santri harus lulus dari seleksi program kelas tersebut, apabila layak maka dapat menjadi anggota dari kelas tersebut.

Dalam metode sorogan dibagi menjadi dua, sebagai berikut:

- Terbimbing

1. Guru membacakan 3-5 kali, santri kemudian menirukan kembali

2. Siswa membaca dan menyetorkan bacaan ke guru.

3. Tenaga pendidik menjelaskan inti maqro'

4. Pengajar bertanya kepada santri mengenai maksud dari kalimat.

- Mandiri.

1. Persiapkan bacaan secara mandiri sesuai bacaan yang diberikan, dan bandingkan dengan kamus bahasa Arab dan buku-buku yang bermakna.

2. Kemudian dilanjutkan dengan menyetor bacaan yang telah ditentukan oleh guru melalui kitab kosongan.

3. Guru menanyakan tarkib dan maksud kalimat, serta memberikan penguatan dan penjelasan tambahan.

Dari paparan diatas, dapat disimpulkan bahwa implementasi metode sorogan dapat dilakukan dengan diadakanya kelas takhasus, sedangkan untuk pemahaman agama islam sendiri mengikuti dengan sendiri ketika proses belajar yakni dengan santri aktif bertanya dan paham akan materi yang diajarkan. Guru berperan penting dalam proses belajar, karena menjadi media bagi para santri bertanya tetang yang berkaitan dengan materi maupun tidak. Jadi pengajar diwajibkan paham akan kelimuan yang akan mereka ajarkan kepada para santri ketika proses belajar berlangsung.

\section{b. Hasil Belajar}

Setiap semester dilakukan penilaian untuk mengetahui tingkat kesiapan seorang anak terhadap pendidikan tertentu dan kegiatan ini memberikan informasi yang konkrit tentang kesiapan siswa untuk sekolah atau tidakSetelah diadakan ujian kenaikan kelas, maka para santri wajib mengasah kemampuan yang ada dengan mengikuti pengajian yang telah disediakan.

Diharapkan dengan menggunakan metode ini para santri dapat dengan mudah memhami isi dan makna baik yang tersirat maupun tidak dalam kitab kuning 
tersebut, sehingga mereka dapat mengamalkanya dengan baik. Serta lebih giat dalam hal belajar karena perjalanan mereka dalam menuntut ilmu tidak berhenti ketika sudah dinyatakan lulus dalam proses evalusi.

\section{c. Keberlanjutan Metode Sorogan}

Metode ini dapat digunakan oleh pihak-pihak atau lembaga pendidikan agama Islam secara keseluruhan. Syarat agar program ini berjalan adalah adanya kurikulum yang telah ditetapkan, desain pembelajaran yang digunakan guru yang menguasai materi nahwu dan shorof, santri yang memenuhi syarat mengikuti kelas tersebut, materi kitab yang akan diajarkan serta evaluasi yang dilakukan sesuai kebutuhan pembelajaran.

d. Bagaimana caranya menerapkan metode sorogan supaya dapat terus ada di lembaga pendidikan islam.

Metode sorogan akan terus digunakan, selama Pondok Pesantren masih berdiri. Karena itu adalah warisan ulama kita terdahulu dan terbukti hingga sekarang hasil dari metode

\section{Faktor-Faktor Penghambat, Pendukung Dan Solusi Dalam implementasi Metode Sorogan.}

\section{a. Faktor Penghambat}

Faktor penghambat Proses Desain Pembelajaran Literasi Kitab Kuning Melalui Metode Sorogan Dalam Meningkatakan Pemahaman Agama Islam Di Pondok Pesantren Tebuireng Jombang, ini meliputi dari faktor lokasi, yang mana lokasi yang sangat sempit dan terkadang satu tempat diisi oleh puluhan kelomopok sehingga tidak efektif ketika pembelajaran, faktor siswa, yang mana kurangnya konsentrasi, capek akibat program full day, dan ketiduran ketika pembelajaran.

\section{b. Faktor Pendukung}

Sedangkan faktor pendukungnya yaitu berupa fasilitas yang sudah disediakan oleh Majelis Ilmi agar dapat menunjang suatu proses pembelajaran, sehingga proses pembelajarannya berjalan sesuai dengan apa yang hendak dicapai oleh pendidik dan Pondok Pesantren Tebuireng Jombang

c. Solusi

Sedangkan upaya dalam mengatasi Sedangkan upaya dalam mengatasi faktor peserta didik yaitu dengan memberikan cerita-cerita yang lucu dan menarik sehingga mampu memotivasi peserta didik agar konsentrasi peserta didik kembali lagi, faktor cuaca, ini menjadi kendala ketika guru berhalangan hadir akibat dari tidak kondusifnya cuaca sehingga mengakibatkan kelas kosong dan diikutkan pada kelas yang lain, sehingga harus memperdayakan peran figure dikamar dan badal pengganti guru takhasus yang tidak bisa hadir ketika jam belajar.

\section{Hasil}

1. Desain Pembelajaran Literasi Kitab Kuning Melalui Metode Sorogan. 
Dalam hal ini, pihak majelis ilmi selaku coordinator bidang kegiatan keilmuan diniyah di pondok Pesantren Tebuireng Jombang, telah menyusun semua materi beserta indikator-indikator dalam pembelajaran yang telah menyesuaikan dengan kurikulum yang telah ditetapkan pihak Yayasan.

2. Implementasi Metode Sorogan Dalam Meningkatakan Pemahaman Agama Islam Pondok Pesantren Tebuireng Jombang?

Melalui adanya kegiatan jam belajar selepas waktu sholat magrib, para santri dapat mengikuti kegiatan yang telah dibuat majelis ilmi dalam proses pembelajaran. Durasi pembelajaran salama satu jam, yang sudah incloud semua materi yang sesuai dengan tingkatan kelas.

3. Faktor-Faktor Penghambat, Pendukung Dan Solusi Dalam implementasi Metode Sorogan.

Hampir disetiap kegiatan yang sudah ada, pasti memiliki kendala dalam setiap pelaksanaan. Tingaal bagaimana kita dapat mencari solusi agar kegiatan tetap berjalan lancar tanpa harus mengubah susunan yang telah ditetapkan.

\section{Kesimpulan}

Berlandaskan ulasan yang mendalam disertai pengecekan ulang dan diskusi Panjang, penelitian ini secara kognitif disimpulkan bahwa:

1. Mengenai Desain Pembelajaran Literasi Kitab Kuning Melalui Metode Sorogan pada Pondok Pesantren Tebuireng Jombang tersendiri dimulai dengan pembacaan Ummul Kitab oleh guru, dilanjutkan dengan mengabsensi para santri, kemudian para santri mulai menyetorkan bacaan berupa kitab tanpa makna kepada guru, setelah proses setoran sudah selesai guru akan memberikan pertanyaan mengenai materi yang dibaca dan materi tambahan, kegiatan ditutup dengan membaca hamdalah.

2. Untuk Implementasi Metode Sorogan Dalam Meningkatkan Pemahaman Agama Islam, melalui program takhasus ini para santri dapat belajar secara itensif dan mengajukan pertanyaan yang berkaitan dengan materi belajar bersama para guru, setalah mendapat penjelasan, maka secara langsung santri akan mempraktikanya dalam setiap kegiatan, seperti memasuki waktu sholat jamaah, para santri akan segera pergi ke masjid tanpa disuruh oleh pembina.

3. Untuk faktor penghambat, pendukung dan solusi pada desain pembelajaran literasi kitab kuning melalui metode sorogan dalam meningkatkan pemahaman Agama Islam di Pondok Pesantren Tebuireng Jombang meliputi penempatan kelompok belajar dalam satu ruangan yang diisi puluhan kelas, kondisi anak-anak yang lelah akibat dari karena sistem full day yang diterapkan, dan cuaca yang kadang tidak kondusif mengakibatkan para guru tidak dapat mengajar ketika jam belajar dimulai. Faktor pendukung sendiri meliputi administrasi yang sudah rapi, fasilitas belajar dan mengajar sudah dilengkapi serta tempat belajar yang layak bagi para santri. 


\section{BIBLIOGRAPHY}

Abdul, G. (2012). Desain Pembelajaran. Yogyakarta: Ombak. Google Scholar

Azra, A., \& Islam, P. (2002). Tradisi dan Modernisasi Menuju Milenium Baru [Islamic Education: Tradition and Modernisation In the New Millennium]. Jakarta: Logos Wacana Ilmu. Google Scholar

Burhan, B. (2007). Penelitian Kualitatif: Komunikasi, Ekonomi, Kebijakan Publik, dan Ilmu Sosial Lainnya. Jakarta: Prenada Media Group. Google Scholar

Dhofier, Z. (1982). Tradisi pesantren: Studi tentang pandangan hidup kyai. LP3ES. Google Scholar

Sanjaya, W. (2019). Strategi pembelajaran berorientasi standar proses pendidikan.

Google Scholar

Van Bruinessen, M. (1995). Kitab kuning pesantren dan tarekat: tradisi-tradisi islam di Indonesia. Mizan. Google Scholar

\section{Copyright holder:}

Zaky Fajar Taufiqurrahman, Habibi Al Amin (2021)

First publication right:

Syntax Literate: Jurnal Ilmiah Indonesia

This article is licensed under:

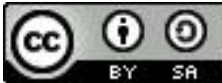

